\title{
Influence of Myrtle Juice and Syrup on Microbiological, Physicochemical and Sensory Features of Goat's Milk Yogurt Made with Indigenous Starter Culture
}

\author{
Nicoletta Pasqualina Mangia*, Marco Ambrogio Murgia, Francesco Fancello, Anna Nudda and Pietrino Deiana \\ Department of Agriculture, University of Sassari, Viale Italia 39, 07100 Sassari, Italy
}

\begin{abstract}
This study evaluated the effect of Myrtle Juice (MJ) and Syrup (MS) on microbiological, physicochemical and sensory features in goat milk yogurt fermented by indigenous Streptococcus thermophilus and Lactobacillus delbruekii subsp. bulgaricus during 30 days of storage. Generally, in all samples, the high LAB number at the end of incubation and the $\mathrm{pH}$ values ranging from 4.1 to 4.6 indicates a good effectiveness of the used starter on fermentation process. L. delbrueckii subsp. bulgaricus compared to $S$. thermophilus was the most abundant in yogurt with MJ (YMJ) after 30 days of storage compared to YMS. On the contrary, S. thermophilus demonstrated the highest viability $(7 \mathrm{log} \mathrm{cfu} / \mathrm{g})$ in the yogurt with MS throughout the storage period. Spoilage and pathogen microorganisms were absent in fresh products and during the storage period. Overall, physicochemical where very similar in all samples, Myrtle juice addition has positively influenced the increase of the lactic acid $L(+)$, acetaldehyde and Free Fatty Acids (FFAs) content. All samples resulted well for flavor and acidity attributes as well as astringency parameter is highly expressed in the YMJ.
\end{abstract}

Keywords: Myrtle juice; Streptococcus thermophilus; Goat Milk; Yogurt; Fermented dairy foods

\section{Introduction}

Fermented dairy foods have constituted a vital part of human diet in many regions of the world since times immemorial. Approximately 400 generic names are applied to the traditional and industrialized fermented milk products manufactured throughout the world. They are mainly related to the type of milk used, the microorganisms involved and the technology applied.

Yogurt can be regarded as functional food [1] and human health benefits have been associated with its consumption [2]. Cow milk yogurts are certainly the most wide spread, well-known and marketed fermented milk products around the world and are recognized as healthy by consumers. Recently, there is an increasing in consumer demand for alternative products, such as goat fermented milk [3] supplemented and/or fortified with different ingredients such as prebiotic compounds, cereals [4] fruits [5] and fibers [6].

Goat milk health benefits such as high digestibility, hypoallergenity, high calcium and high essential amino acids content compared to cow and sheep milks have been reported [7-10]. Furthermore, goat milk contains similar amount of vitamin B6 and pantothenic acid, more niacin (about 3.5-fold), but less vitamin B12 (about 4-fold) and folic acid (approximately 6-fold) than bovine milk [11]. Folic acid deficiency is one of the main charges against the goat's milk to be used as a product for infant nutrition. To overcome this issue, folate bio-enrichment of goat dairy products was done using native folate producing starter cultures [12]. Recent studies furthermore demonstrated that raw goat milk is a source of potential bio-preservatives cultures for fermented food production $[13,14]$. In general, goat milk products present an unpleasant "goaty" flavor, but the evaporation procedure used in the yogurt preparation process improves the consistency and reduces this flavor in the end product [15]. Myrtle (Myrtus communis L.) is a typical spontaneous plant of the Mediterranean area, it is widely used in Sardinia (Italy) to produce a typical liqueur by hydroalcoholic infusion [16], and the wood smoke of myrtle is used for flavoring meat or cheeses, such as the PDO Fiore Sardo cheese.
Myrtus leaves hydroalcoholic extracts and essential oils have been shown good biological activity such as antioxidant [17] and antimicrobial activities on some pathogenic bacteria particularly Escherichia coli, Listeria monocytogenes, S. aureus and Candida albicans [18]. Nowadays there is a high demand by consumers for alternatives to cow's milk due to problems associated with allergenicity, gastrointestinal disorders and desire for novel dairy products with enhanced healthy properties [10]. Numerous studies have shown that several fruits increase the nutritional value to food, because they are potential beneficial for human health [19]. Therefore supplementation of goat's milk yoghurt with myrtle berries can enhance its nutritional quality and provide therapeutic value too.

The objectives of this study were to develop a new goat milk yoghurt added with myrtle berries juice and syrup and assessed for evaluate: i) a possible inhibitory effects of these on the yogurt starter microorganisms and their activity; ii) a possible negative influence on the physicochemical and sensory characteristics of the goat's milk yoghurt during the storage period. To our knowledge, this is the first study of myrtle juice and syrup effects on the microbiological and physicochemical parameters of goat milk yogurt.

\section{Materials and Methods}

\section{Culture starter}

Streptococcus thermophilus SL1 (S. thermophilus) and Lactobacillus

*Corresponding author: Nicoletta Pasqualina Mangia, Department of Agriculture University of Sassari, Viale Italia 39, 07100 Sassari, Italy, Tel: 079 229287; Fax:+39 079 229370; E-mail: nmangia@uniss.it

Received September 19, 2014; Accepted November 05, 2014; Published November 12, 2014

Citation: Mangia NP, Murgia MA, Fancello F, Nudda A, Deiana P (2014) Influence of Myrtle Juice and Syrup on Microbiological, Physicochemical and Sensory Features of Goat's Milk Yogurt Made with Indigenous Starter Culture. J Microb Biochem Technol 6: 370-374. doi:10.4172/1948-5948.1000171

Copyright: (c) 2014 Mangia NP, et al. This is an open-access article distributed under the terms of the Creative Commons Attribution License, which permits unrestricted use, distribution, and reproduction in any medium, provided the original author and source are credited 
Citation: Mangia NP, Murgia MA, Fancello F, Nudda A, Deiana P (2014) Influence of Myrtle Juice and Syrup on Microbiological, Physicochemical and Sensory Features of Goat's Milk Yogurt Made with Indigenous Starter Culture. J Microb Biochem Technol 6: 370-374. doi:10.4172/19485948.1000171

delbrueckii subsp. bulgaricus LY1 (L. bulgaricus) strains, isolated from goat milk and with suitable technological properties [12] were used as starter cultures. Lactobacilli strains to be used in the experimental batches were grown overnight in MRS medium (Oxoid, Milan, Italy) at $42^{\circ} \mathrm{C}$, streptococci in $\mathrm{M} 17$ medium (Oxoid) at $42^{\circ} \mathrm{C}$.

\section{Preparation of juice and syrup mirtus}

Myrtus berries (collected in Sardinia, Italy) were cleaned under running water and pasteurized at $78^{\circ} \mathrm{C}$ for 30 minutes and then crushed with a mixer (Turbo Homogeneizer HMHF, Pbi). Crushed berries were squeezed with a press to obtain the juice. After than the juice was filtered by cheese cloth; the syrup was obtained by adding saccarose to the filtered juice up to have a final concentration of $20 \%$. The syrup was obtained by adding to the juice $20 \%$ of saccarose and hand mixing.

\section{Experimental yogurt manufacturing}

For this work 150 liters of goat milk were pasteurized at $90^{\circ} \mathrm{C}$ for $30 \mathrm{~s}$ and cooled to $42^{\circ} \mathrm{C}$.

In order to verify the action of the myrtle berries (juice and syrup) in the best possible manner, three separate batchs of 50 liters of milk were performed: batch A (Y): S. thermophilus + L. bulgaricus; batch B (YMJ): S. thermophilus + L. bulgaricus + myrtle juice (3\%); batch C (YMS) $S$. thermophilus + L. bulgaricus + mirtus syrup $(3 \%)$. The goat milk was dispensed directly in $125 \mathrm{~g}$ plastic containers and then inoculated ( $\sim 6 \mathrm{log}$ ufc/mL of milk) with the S. thermophilus and L. bulgaricus starter culture in $1: 1$ ratio and incubated at $42^{\circ} \mathrm{C}$ for $4 \mathrm{~h}$. At the end of incubation period, the containers were immediately cooled and kept in a cold room at $5^{\circ} \mathrm{C}$ for 30 days. Raw milk and also four yoghurt samples were collected at the end of the incubation $(t=0)$ and after 5,15 and 30 days of storage and microbiological and physicochemical analysis were carried out. Sensory evaluation was performed at 30 days of storage.

\section{Microbiological analysis}

Raw goat milk and yogurt $(10 \mathrm{ml})$ samples were homogenized in 90 $\mathrm{ml}$ of sterile Ringer's solution (Oxoid, Mila, IT) for $2 \mathrm{~min}$ in a Stomacher Lab Blender 80 (PBI, Milan, IT). Aliquots $(1 \mathrm{ml})$ were 10 -fold diluted in Ringer's solution (Oxoid, Milan, IT) plated on the specific media used to quantify different species and microbial groups. Lactobacilli and lactic streptococci were quantified after anaerobic incubation (Gas-Pack, Oxoid, Milan, IT) at $42^{\circ} \mathrm{C}$ for $48 \mathrm{~h}$ on acidified (pH 5.4) MRS and M17 agar (Oxoid, Milan, IT) respectively; staphylococci and yeasts, were quantified using the method described by Mangia et al. [20]; faecal coliforms were counted as described by Mangia et al. [21]; aerobic spore-forming bacteria were counted on Nutrient agar (Oxoid, Milan, IT) [22]; anaerobic spore-forming bacteria were enumerated after samples heat treatment $\left(80^{\circ} \mathrm{C}\right.$ for $\left.10 \mathrm{~min}\right)$, inoculation on DRCM broth (Oxoid, Milan, IT) and incubation at $37^{\circ} \mathrm{C}$ for $48 \mathrm{~h}$ in anaerobic conditions (MPN method).

\section{Determination of physicochemical parameters}

Yoghurt $\mathrm{pH}$ value was determined with a $\mathrm{pH}$-meter (Crison Instruments SA, Barcelona, Spain). Acidity determination was carried out in $10 \mathrm{ml}$ of milk/yogurt titrated with $0.1 \mathrm{~N} \mathrm{NaOH}$, phenolphthalein was used as indicator and acidity was expressed as percentage of lactic acid; Dry Mater (DM), ash, fat and chlorides were monitored according to IDF Standard [23-26] respectively; Total Nitrogen (TN) were determined by Kjeldahl according to Butikofer et al. [27]; FFAs were extracted from yogurt and analysed by gas chromatography using the procedures described by De Jong and Badings [28], with some minor modifications detailed by Madrau et al. [29]. Briefly, FFA was extracted with three steps of lipid extraction from yogurt mixed with $3 \mathrm{~g}$ of anhydrous sodium sulphate and $0.3 \mathrm{ml}$ of sulphuric acid. 3 $\mathrm{mL}$ of diethyl ether/heptane (1:1 v/v) was added and vortex for $3 \mathrm{~min}$. This operation was repeated three times. The extracted FFA are then isolated by using alumina, and subsequently desorbed with $5 \mathrm{~mL}$ of ether containing $6 \%$ formic acid. FFAs were separated using a fused silica capillary column Nukol ( $15 \mathrm{~m}, 0.53 \mathrm{~mm}$ I.D., $0.50 \mathrm{~mm}$ Df; SigmaAldrich Co.), using an HP 5890 series II gas chromatograph (HewlettPackard Co.), equipped with an auto-sampler, flame ionisation detector and a data acquisition system (HP Chemstation Rev. A.06.03 software; Hewlett-Packard Co.). The sum of FFA was calculated and used in the present study. Lactose, glucose, galactose, $\mathrm{D}(-)$ and $\mathrm{L}(+)$ lactic acid and acetaldehyde were quantified using enzymatic assays (Boehringer Mannheim, R-Biopharm, Germany).

\section{Sensory analysis}

Sensory analysis was carried out in agreement with those reported on The Sensory Evaluation of Dairy Products [30] and the IDF standard methods [31-33]. Flavor, consistency, acidity, taste, sweet, astringent and animal-like parameters (aromatics associated with barns and stock) [34] were evaluated by a trained panel of 10 members using a five-point score system in accordance with their preference hedonistic (5 excellent, 1 unacceptable). The sensory profiles were conducted on coded samples at 30 days of storage. Each judge of the 10 sensory panelists has performed the test three times with an interval of 24 hours between sessions.

\section{Statistical analysis}

Microbiological and physicochemical analyses were carried out in triplicate on yogurt samples from each batch $(n=3)$. Mean values of microbiological and physicochemical data at a specific storage time for each yoghurt were compared using the Student's T test and differences were deemed statistically significant at $\mathrm{P}<0.05$. Sensory analysis data were analyzed with Statgraphics Centurion version XV.

\section{Result and Discussion}

\section{Microbiological analysis}

Overall the microbiological quality of milk used in this experiment was acceptable (Table 1). The initial count of lactobacilli and lactic streptococci in the raw milk were higher than counts found in raw goat milk by others authors [35,36], even though the heat treatment applied eliminates all microbial groups of the raw milk (data not shown).

$\mathrm{LAB}$ numbers increased during the incubation time reaching higher count values compared to the results of Ranadheera et al [3], but similar at the results of Xanthopoulos et al. [37]. On average the counts of $L$. bulgaricus in the different experimental products decreased about $2 \log$ units during the storage period with different behaviour between the different batches. In Y and YMJ the counts of L. bulgaricus increased up to 15 days and then decreased slightly at 30 days of storage. While in the YMS the counts decreased after 5 days of storage. These trends disagreed with the results of Eissa et al. [38] which showed that L. bulgaricus count in caprine yoghurt increased in the first ten days of storage and then decreased. The S. thermophilus counts decreased during storage; this is agreed with the results of Ranadheera et al. [3] but in contrast with several previous studies that detected in goat's milk yogurt [39] and cow's milk yogurt [40] a slight increase of $S$. thermophilus counts in the first week of storage. In particular, S. thermophilus count decrease was variable depending of the batch. In $\mathrm{Y}$ and $\mathrm{YMJ}$ the initial counts decreased at 30 days of storage more 
Citation: Mangia NP, Murgia MA, Fancello F, Nudda A, Deiana P (2014) Influence of Myrtle Juice and Syrup on Microbiological, Physicochemical and Sensory Features of Goat's Milk Yogurt Made with Indigenous Starter Culture. J Microb Biochem Technol 6: 370-374. doi:10.4172/19485948.1000171

\begin{tabular}{|c|c|c|c|c|c|c|c|c|c|c|c|c|c|}
\hline & Raw milk & $\mathbf{Y}$ & YMJ & YMS & $\mathbf{Y}$ & YMJ & YMS & $\mathbf{Y}$ & YMJ & YMS & $\mathbf{Y}$ & YMJ & YMS \\
\hline Time & & \multicolumn{3}{|c|}{ to } & \multicolumn{3}{|c|}{5} & \multicolumn{3}{|c|}{15} & \multicolumn{3}{|c|}{30} \\
\hline \multicolumn{14}{|l|}{ Microbial groups } \\
\hline $\begin{array}{l}\text { Lactobacillil } \\
\text { L. bulgaricus }\end{array}$ & $5.0 \pm 0.01$ & $9.8 \pm 0.20^{b}$ & $10.8 \pm 1.05^{\mathrm{a}}$ & $9.2 \pm 0.01^{c}$ & $9.8 \pm 0.11^{a}$ & $9.8 \pm 0.01^{a}$ & $8.8 \pm 2.10^{b}$ & $9.9 \pm 0.01^{a}$ & $9.9 \pm 0.01^{a}$ & $8.3 \pm 4.00^{b}$ & $7.98 \pm 0.26^{b}$ & $8.8 \pm 0.01^{\mathrm{a}}$ & $6.9 \pm 0.01^{c}$ \\
\hline $\begin{array}{l}\text { StreptococcilS. } \\
\text { thermophilus }\end{array}$ & $5.3 \pm 0.15$ & $9.3 \pm 0.52^{b}$ & $9.7 \pm 0.90^{\mathrm{a}}$ & $9.2 \pm 0.05^{c}$ & $7.0 \pm 1.73^{b}$ & $7.2 \pm 0.24^{b}$ & $9.1 \pm 3.09^{a}$ & $6.0 \pm 0.01^{b}$ & $6.0 \pm 0.09^{b}$ & $9.0 \pm 2.70^{\mathrm{a}}$ & $5.4 \pm 0.05^{b}$ & $4.3 \pm 0.26^{c}$ & $7.5 \pm 2.99^{a}$ \\
\hline Fecal coliforms & $2.6 \pm 0.10$ & $<1$ & $<1$ & $<1$ & $<1$ & $<1$ & $<1$ & $<1$ & $<1$ & $<1$ & $<1$ & $<1$ & $<1$ \\
\hline Staphylococci NC & $3.3 \pm 2.20$ & $<1$ & $<1$ & $<1$ & $<1$ & $<1$ & $<1$ & $<1$ & $<1$ & $<1$ & $<1$ & $<1$ & $<1$ \\
\hline Yeasts and Moulds & $2.4 \pm 0.01$ & $<1$ & $<1$ & $<1$ & $<1$ & $<1$ & $<1$ & $<1$ & $<1$ & $<1$ & $<1$ & $<1$ & $<1$ \\
\hline ASFB* $^{*}$ & $3.0 \pm 0.13$ & $<1$ & $<1$ & $<1$ & $<1$ & $<1$ & $<1$ & $<1$ & $<1$ & $<1$ & $<1$ & $<1$ & $<1$ \\
\hline $\mathrm{AnSFB}^{*}$ & 7 & $<3$ & $<3$ & $<3$ & $<3$ & $<3$ & $<3$ & $<3$ & $<3$ & $<3$ & $<3$ & $<3$ & $<3$ \\
\hline
\end{tabular}

Presented values are the average \pm SD. ASFB: Aerobic spore-forming bacteria; AnSFB: Anaerobic spore-forming bacteria. ${ }^{*}$ MPN Method. For each sampling time, values in the same row with different superscript letters differed significantly $(P<0.05)$.

Table 1: Evolution of microbial groups (log cfu $\mathrm{g}^{-1}$ ) of raw milk, yogurt (Y), yogurt added myrtle juice (YMJ) and yogurt added myrtle syrup (YMS) at the end of incubation (t0) and at 5,15 and 30 days of storage at $5^{\circ} \mathrm{C}$.

\begin{tabular}{|c|c|c|c|c|c|c|c|c|c|c|}
\hline Samples & $\begin{array}{l}\text { Pasteurised } \\
\text { milk }\end{array}$ & $\mathbf{Y}$ & YMJ & YMS & $\mathbf{Y}$ & YMJ & YMS & $\mathbf{Y}$ & YMJ & YMS \\
\hline Time & & \multicolumn{3}{|c|}{$\mathbf{T}_{0}$} & \multicolumn{3}{|c|}{15} & \multicolumn{3}{|c|}{30} \\
\hline $\mathrm{pH}$ & 6.48 & $4.10^{\mathrm{a}}$ & $4.67^{b}$ & $4.50^{\mathrm{b}}$ & $4.07^{\mathrm{a}}$ & $3.82^{\mathrm{b}}$ & $4.00^{\mathrm{a}}$ & $4.03^{a}$ & $3.86^{b}$ & $3.92^{b}$ \\
\hline Acidity $\%$ & 0.19 & $1.12^{\mathrm{a}}$ & $0.75^{\mathrm{a}}$ & $0.77^{a}$ & $1.19^{a}$ & $1.15^{\mathrm{a}}$ & $1.32^{\mathrm{a}}$ & $1.20^{\mathrm{a}}$ & $1.26^{\mathrm{a}}$ & $1.25^{\mathrm{a}}$ \\
\hline Lactose $\mathrm{g} / 100 \mathrm{~g}$ & 5.68 & $2.82^{\mathrm{a}}$ & $2.52^{\mathrm{a}}$ & $2.99^{a}$ & $2.27^{a}$ & $2.35^{\mathrm{a}}$ & $2.50^{\mathrm{a}}$ & $2.10^{a}$ & $1.90^{\mathrm{a}}$ & $2.20^{a}$ \\
\hline Glucose g/100 g & - & 0.01 & 0 & 0 & 0 & 0 & 0 & 0 & 0 & 0.01 \\
\hline Galactose $\mathrm{g} / 100 \mathrm{~g}$ & - & $1.44^{a}$ & $0.69^{b}$ & $0.83^{b}$ & $1.18^{a}$ & $0.67^{b}$ & $0.69^{b}$ & $1.20^{\mathrm{a}}$ & $0.83^{b}$ & $0.71^{c}$ \\
\hline Lactic acid D(-) & - & $2.23^{a}$ & $2.57^{a}$ & $3.46^{b}$ & $2.56^{\mathrm{a}}$ & $2.32^{\mathrm{a}}$ & $3.82^{b}$ & $3.47^{a}$ & $4.68^{b}$ & $4.72^{b}$ \\
\hline Lactic acid L(+) & - & $7.70^{\mathrm{a}}$ & $8.32^{a}$ & $6.90^{\mathrm{b}}$ & $8.90^{a}$ & $8.56^{a}$ & $6.69^{b}$ & $9.00^{a}$ & $9.12^{\mathrm{a}}$ & $6.77^{b}$ \\
\hline Acetaldehyde & - & $3.70^{\mathrm{a}}$ & $4.80^{\mathrm{b}}$ & $2.40^{\mathrm{c}}$ & $3.40^{\mathrm{a}}$ & $3.00^{\mathrm{a}}$ & $0.40^{c}$ & $3.30^{\mathrm{a}}$ & $2.80^{b}$ & $0.40^{c}$ \\
\hline DM & - & $16.13^{\mathrm{a}}$ & $15.82^{\mathrm{a}}$ & $16.86^{a}$ & $16.12^{\mathrm{a}}$ & $15.58^{a}$ & $16.68^{a}$ & $16.02^{a}$ & $15.69^{a}$ & $16.90^{\mathrm{b}}$ \\
\hline Ash & - & $0.91^{a}$ & $0.87^{a}$ & $0.84^{a}$ & $0.92^{\mathrm{a}}$ & $0.88^{a}$ & $0.85^{a}$ & $0.95^{a}$ & $0.93^{a}$ & $0.85^{b}$ \\
\hline Fat & - & $5.58^{a}$ & $4.07^{b}$ & $4.83^{c}$ & $5.30^{\mathrm{a}}$ & $5.40^{\mathrm{a}}$ & $4.78^{a}$ & $4.78^{a}$ & $4.92^{\mathrm{a}}$ & $4.74^{a}$ \\
\hline Chlorides \% & - & $0.47^{a}$ & $0.52^{\mathrm{a}}$ & 0.44 & $0.47^{a}$ & $0.48^{a}$ & $0.45^{\mathrm{a}}$ & $0.49^{a}$ & $0.47^{a}$ & $0.41^{a}$ \\
\hline $\mathrm{TN}$ & - & $4.25^{\mathrm{a}}$ & $4.07^{a}$ & $3.95^{\mathrm{a}}$ & $4.15^{\mathrm{a}}$ & $4.10^{\mathrm{a}}$ & $3.90^{\mathrm{a}}$ & $4.34^{a}$ & $4.19^{a}$ & $3.96^{\mathrm{a}}$ \\
\hline FFA & - & $69.62^{a}$ & $55.70^{\mathrm{b}}$ & $47.47^{c}$ & $62.80^{a}$ & $70.80^{\mathrm{b}}$ & $73.10^{\mathrm{b}}$ & $79.36^{a}$ & $85.06^{b}$ & $77.25^{\mathrm{a}}$ \\
\hline
\end{tabular}

For each sampling time, values in the same row with different superscript letters differed significantly $(P<0.05)$.

Table 2: Physicochemical analysis of pasteurized milk, yogurt ( $Y$ ), yogurt added myrtle juice (YMJ) and yogurt added myrtle syrup (YMS) at the end of incubation (t 0 ), at 15 and 30 days of storage at $5^{\circ} \mathrm{C}$.

than $4 \log$ units while in the YMS it decreased about $1.5 \log$ units. In contrast with previous observations by Dave and Shah $[41,42]$ and Eissa et al. [38], S. thermophilus count in Y and YMJ remained below that of $L$. bulgaricus at the end of the storage period. This different rate of decrease can be explained by the better tolerance to higher concentration of sucrose in YMS yogurt of $S$. thermophilus compared to L. bulgaricus [43] rather than to a negative effect of the myrtle itself. The addition of juice myrtle to yoghurt have a positive effect on the growth of lactobacilli, the count in fact, was significantly higher respect to the other two experimental trials during the entire storage period. A similar stimulant effect of fruits juice was previously detected in goat's yogurt supplemented with aronia juice [44]. However the effect of natural fruit juices on yogurt starter culture growth has been reported to be species and strain specific [45]. Though, high initial temperature $\left(42^{\circ} \mathrm{C}\right)$ used in these trials favor the lactobacilli growth; Güler-Akın and Akın [39] observed a significantly higher number of L. bulgaricus in yogurt incubated at $42^{\circ} \mathrm{C}$ rather than at $37^{\circ} \mathrm{C}$. L. bulgaricus is considered the main responsible of the low $\mathrm{pH}$ attained in the yogurt after 1 day of storage, view the low rate of acidification of $S$. thermophilus. Indeed, has been showed that this species take about $10 \mathrm{~h}$ of incubation to reach $\mathrm{pH} 4.5$ in goat's milk [46].

Spoilage and pathogens bacteria were absent in fresh products and also throughout the storage period. This result reflects the effectiveness of the heat treatment on the milk used to make yoghurt, the absence of contamination during the process and the use of low temperature throughout storage. Furthermore due to its low $\mathrm{pH}$, yogurt exhibits unsuitable environment for the growth of pathogens and spoilage microorganisms.

\section{Physicochemical analysis}

The results of the physicochemical analysis are shown in Table 2. DM, ash, fat, chlorides and TN parameters were much like in all samples and the acidification process took place with regular increases in acidity. In all samples, the evolution of acidity and $\mathrm{pH}$ over time are very similar. However, at the end of incubation phase the $\mathrm{pH}$ values ranged from 4.10 to 4.6 . The degradation of lactose occurred mainly during the incubation phase and did not undergo major changes during storage as well as glucose. The galactose instead is degraded only in part, because most of the strains of $S$. thermophilus are galactose negative (Gal-) [47].

The increase of lactic acid $\mathrm{L}(+)$ was particularly evident for batches $\mathrm{Y}$ and $\mathrm{YMJ}$ where lactobacilli were more numerous than streptococci LAB and also presented higher acidification activity than S. thermophilus. The ratio of $\mathrm{L}(+) / \mathrm{D}(-)$ lactic acid could be used to assess the quality of yoghurt which is of great dietary interest and puts fermented goat milk in the "good yoghurt" category [48]. 
Citation: Mangia NP, Murgia MA, Fancello F, Nudda A, Deiana P (2014) Influence of Myrtle Juice and Syrup on Microbiological, Physicochemical and Sensory Features of Goat's Milk Yogurt Made with Indigenous Starter Culture. J Microb Biochem Technol 6: 370-374. doi:10.4172/19485948.1000171

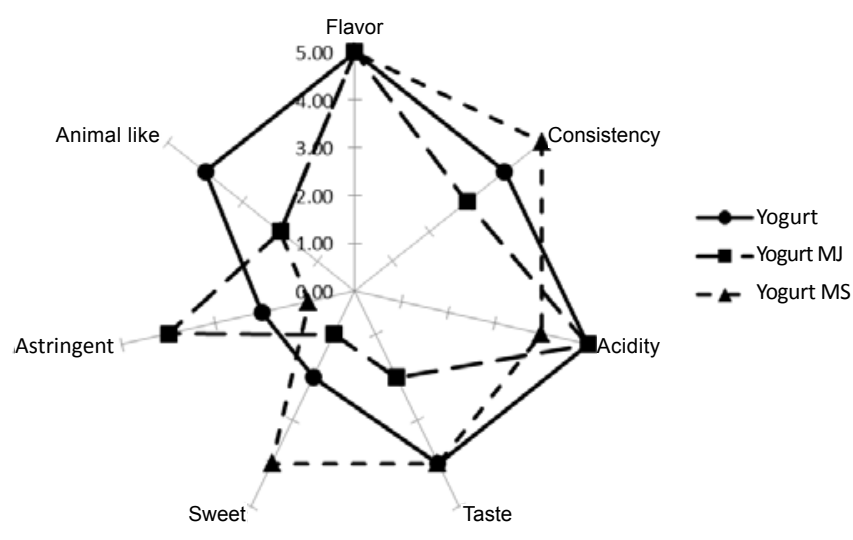

Figure 1: Sensory attributes of Yogurt (Y), Yogurt Added Myrtle Juice (YMJ) and Yogurt Added Myrtle Syrup (YMS) at 30 days of storage at $5^{\circ} \mathrm{C}$.

The high number of L. bulgaricus in Y and YMJ product could also explain the higher acetaldehyde concentration than YMS. Indeed, between yoghurt micro-organismes L. bulgaricus is the major acetaldehyde-producing specie [49,50]. The lower contents of acetaldehyde in the YMS samples can be attributed to the reductase activity of $S$. thermophilus present in high numbers in this type of yogurt [33]. Moreover, the acetaldehyde concentrations of $\mathrm{Y}$ and YMS were higher than reported in goat set-up yogurt manufactured by potential probiotic strains [37] and of all secondary aromatic metabolites of L. bulgaricus is the most important [47]. FFA content increased considerably during storage in all samples (Table 2) but at the end of storage their amount was significantly higher in YMS. Formisano et al. [51] observed that FFA levels in yoghurt increased over a period of 20 days in cold storage, due in particular to the increase of C14-C18:2 fatty acid [52].

\section{Sensory analysis}

The results of the sensory analysis (Figure 1) show that the flavor is well expressed in all products. The consistency is well expressed in $\mathrm{Y}$, decreased with the addition in YMJ and improved with the syrup addition. The acidity perception is probably influenced by the glucose presence, in fact in YMS is less perceived. Parameter astringency due to the presence of tannins [34], is highly expressed in the yogurt with the myrtus juice and is hidden by the presence of sugar in yogurt with syrup. The added of juice and syrup myrtle berries masked the animal like parameter, which is perceived more in natural yogurt. Statistical analysis showed that there are no differences between the panelists and even between sessions.

\section{Conclusion}

Our study indicated that myrtle juice and syrup don't affect indigenous LAB fermentative activity and preserve their cells viability in goat's milk yogurt during storage. This behavior is evident in particular for Lactobacillus bulgaricus in YMJ as well as Streptococcus thermophilus in YMS. Myrtle juice addition has positively influenced the increase of the lactic acid $\mathrm{L}(+)$ and acetaldehyde content. These preliminary data indicate that the use of goat's milk, a selected indigenous starter culture and juice myrtle may be suitable for setting up a new yogurt with balanced nutritional characteristics and rich in live Lactic Acid Bacteria, though further research is certainly needed.

\section{References}

1. Kim SH, Oh S (2013) Fermented milk and yogurt. In Milk and Dairy Products in Human Nutrition: Production, Composition and Health. Editor(s): Young W. Park, George F.W. Haenlein, pp. 338-356.

2. Donovan SM, Shamir R (2014) Introduction to the yogurt in nutrition initiative and the First Global Summit on the health effects of yogurt. Am J Clin Nutr 99: 1209S-11S.

3. Senaka Ranadheera C, Evans CA, Adams MC, Baines SK (2012) Probiotic viability and physico-chemical and sensory properties of plain and stirred fruit yogurts made from goat's milk. Food Chem 135: 1411-1418.

4. Coda R, Lanera A, Trani A, Gobbetti M, Di Cagno R (2012) Yogurt-like beverages made of a mixture of cereals, soy and grape must: microbiology, texture, nutritional and sensory properties. Int J Food Microbiol 155: 120-127.

5. Eke MO, Olaitan NI, Sule HI (2013) Nutritional evaluation of yoghurt-like product from baobab (adansonia digitata) fruit pulp emulsion and the micronutrient content of baobab leaves. Advance J Food Sci Technol 5: 1266-1270.

6. Velez-Ruiz JF, Hernandez-Carranza P, Sosa-Morales M (2013) Physicochemical and flow properties of low-fat yogurt fortified with calcium and fiber. J Food Processing Preservation 37: 210-221.

7. Bernacka H (2011) Health-promoting properties of goat milk. Medycyna Weterynaryjna 67: 507-511.

8. Robinson F (2001) Goats milk-a suitable hypoallergenic alternative? British Food J 103: 198-208.

9. Mc Cullough Fiona SW (2003) Nutritional evaluation of goat's milk, British Food J 105: 239-251.

10. Haenlein GFW (2004) Goat milk in human nutrition. Small Rum Res 51: 155-163.

11. Food and Agriculture Organization of the United Nations (2013) MILK and dairy products in human nutrition. Ellen Muehlhoff Anthony Bennett Deirdre McMahon Editors. Rome (Italy).

12. Sanna MG, Mangia NP, Garau G, Murgia MA, Massa T, Franco A, Deiana P (2005) Selection of folate-producing lactic acid bacteria for improving fermented goat milk. Italian J Food Sci 17: 143-154.

13. Schirru S, Todorov SD, Favaro L, Mangia NP, Basaglia M, et al. (2012) Sardinian goat's milk as source of bacteriocinogenic potential protective cultures. Food Control 25: 309-320.

14. Schirru S, Favaro L, Mangia NP, Basaglia M, Casella S, et al. (2014) Comparison of bacteriocins production from Enterococcus faecium strains in cheese whey and optimised commercial MRS medium. Annals of Microbiol 64: 321-331.

15. Hadland G, Hoffmann T (1974) Structural modification of goats' milk for production of fermented milks. in: Proc. XIX Int. Dairy Congr. 1E. 740.

16. Montoro P, Tuberoso Cl, Piacente S, Perrone A, De Feo V, et al. (2006) Stability and antioxidant activity of polyphenols in extracts of Myrtus communis L. berries used for the preparation of myrtle liqueur. J Pharm Biomed Anal 41: 1614-1619.

17. Rosa A, Melis MP, Deiana M, Atzeri A, Appendino G, et al. (2008) Protective effect of the oligomeric acylphloroglucinols from Myrtus communis on cholesterol and human low density lipoprotein oxidation. Chem Phys Lipids 155: 16-23.

18. Aleksic V, Knezevic $P$ (2014) Antimicrobial and antioxidative activity of extracts and essential oils of Myrtus communis L. Microbiol Res 169: 240-254.

19. do Espírito Santo AP, Cartolano NS, Silva TF, Soares FA, Gioielli LA, et al (2012) Fibers from fruit by-products enhance probiotic viability and fatty acid profile and increase CLA content in yoghurts. Int J Food Microbiol 154: 135144.

20. Mangia NP, Garau G, Murgia MA, Bennani A, Deiana P (2014) Influence of autochthonous lactic acid bacteria and enzymatic yeast extracts on the microbiological, biochemical and sensorial properties of Lben generic products. J Dairy Res 81: 193-201.

21. Mangia NP, Murgia MA, Garau G, Fancello F, Deiana P (2013) Suitability Of Selected Starter Cultures For Pecorino Sardo Dolce Cheese Manufacturing: Influence On Microbial Composition, Nutritional Value And Sensory Attributes. Int J Dairy Technol 66: 543-551. 
Citation: Mangia NP, Murgia MA, Fancello F, Nudda A, Deiana P (2014) Influence of Myrtle Juice and Syrup on Microbiological, Physicochemical and Sensory Features of Goat's Milk Yogurt Made with Indigenous Starter Culture. J Microb Biochem Technol 6: 370-374. doi:10.4172/19485948.1000171

22. Sanguinetti AM, Del Caro A, Mangia NP, Secchi N, Catzeddu P, et al. (2011) Quality changes of fresh filled pasta during storage: influence of modified atmosphere packaging on microbial growth and sensory properties. Food Sci Technol Int 17: 23-29.

23. IDF (1982) Cheese and processed cheese. Determination of the total solid content (reference method). Standard 4A:1982. Brussels, Belgium: International Dairy Federation.

24. IDF, (1964) Determination of the ash content of processed cheese products. Standard 27:1964. Brussels, Belgium: International Dairy Federation.

25. IDF, (1986) Cheese and processed cheese products. Determination of fat content. Gravimetric method (reference method). Standard 5B:1986. Brussels, Belgium: International Dairy Federation.

26. IDF, (1988a) Cheese and processed cheese products. Determination of chloride content (potentiometric titration method). Standard 88A:1988. Brussels, Belgium: International Dairy Federation.

27. Bütikofer U, Rüegg M, Ardö Y (1993) "Determination of nitrogen fractions in cheese: evaluation of a collaborative study" LWT- Food Sci Technol 26: 271275 .

28. De Jong C, Badings HT, (1990) Determination of free fatty acids in milk and cheese. Procedures for extraction, clean up, and capillary gas chromatographic analysis. J High Resolution Chromatogr 13: 94-98.

29. Madrau MA, Mangia NP, Murgia MA, Sanna, MG, Garau G, Leccis L, Caredda $M$, Deiana P (2006) Employment of autochthonous microflora in Pecorino Sardo cheese manufacturing and evolution of physicochemical parameters during ripening. Int Dairy J 16: 876-885.

30. Don Tribby (2009) In Clark S., Costello M., Drake M.A. and Bodyfelt F. The Sensory Evaluation of Dairy Products. Chapter 8, pp $191-223$.

31. ISO 22935-1:2009 (IDF 99-1: 2009) - Milk and milk products -- Sensory analysis -- Part 1: General guidance for the recruitment, selection, training and monitoring of assessors.

32. ISO 22935-2:2009 (IDF 99-2: 2009) - Milk and milk products -- Sensory analysis -- Part 2: Recommended methods for sensory evaluation.

33. ISO 22935-3:2009 (IDF 99-3: 2009) - Milk and milk products -- Sensory analysis -- Part 3: Guidance on a method for evaluation of compliance with product specifications for sensory properties by scoring.

34. Isleten M, Karagul-Yuceer Y (2006) Effects of dried dairy ingredients on physical and sensory properties of nonfat yogurt. J Dairy Sci 89: 2865-2872.

35. Fatichenti F, Deiana P, Farris GA, Soggia G (1979) Études microbiologiques sur le lait et le fromage de chèvre en Sardigne. Le Lait 587: 387-399.

36. Foschino R, Invernizzi A, Barucco R, Stradiotto K (2002) Microbial composition, including the incidence of pathogens, of goat milk from the bergamo region of italy during a lactation year. J Dairy Res 69: 213-225.

37. Xanthopoulos V, Ipsilandis CG, Tzanetakis N (2012) Use of a selected multistrain potential probiotic culture for the manufacture of set-type yogurt from caprine milk. Small Rum Res 106: 145-153.
38. Eissa EA, Ahmed IAM, Yagou AEA, Babiker EE (2010) Physicochemical, microbiological and sensory characteristics of yoghurt produced from goat milk. Livestock Res Rural Development 22: 8.

39. Güler-Akin MB, Akin MS, (2007) Effects of cysteine and different incubation temperatures on the microflora, chemical composition and sensory characteristics of bio-yoghurt made from goat's milk. Food Chem 100: 788-793.

40. Birollo GA, Reinheimer JA, Vinderola CGV (2000) Viability of lactic acid microflora in different types of yoghurt. Food Res Int 33:799-805.

41. Dave RI, Shah NP (1997a) Effectiveness of ascorbic acid as an oxygen scavenger in improving viability of probiotic bacteria in yoghurts made with commercial starter cultures. Int Dairy J 7: 435-443.

42. Dave RI, Shah NP (1997b) Effect of cysteine on the viability of yoghurt and probiotic bacteria in yoghurts made with commercial starter cultures. Int Dairy J 7: 537-545.

43. Tamine AY, Robinson RK (2007) Tamime and Robinson's Yoghurt, 3rd Edition Science and Technology, Woodhead Publishing

44. Boycheva S, Dimitrov T, Naydenova N, Mihaylova G (2011) Quality characteristics of yogurt from goat's milk, supplemented with fruit juice. Czech J Food Sci 29: 24-30

45. Vinderola CG, Costa GA, Regenhardt S, Reinheimer JA (2002) Influence of compounds associated with fermented dairy products on the growth of lactic acid starter and probiotic bacteria. Int D J 12: 579-589.

46. Martin-Diana AB, Janer C, Peláez C, Requena T (2003) Development of a fermented goat's milk containing probiotic bacteria. Int Dairy J 13: 827-833.

47. Anbukkarasi K, Uma Maheswari T, Hemalatha T, Nanda DK, Singh P et al (2014) Preparation of low galactose yogurt using cultures of Gal+ Streptococcus thermophilus in combination with Lactobacillus delbrueckii ssp. bulgaricus. J Food Sci Technol 51: 2183-2189.

48. Xanthopoulos V, Petridis D, Tzanetakis N (2001) Characterization and classification of Streptococcus thermophilus and Lactobacillus delbrueckil subsp. bulgaricus strains isolated from traditional greek yogurts. J Food Sci 67:747-752.

49. Pinto SM, Clemente MDG, De Abreu LR (2009) Behaviour of volatile compounds during the shelf life of yoghurt. Int J Dairy Technol 62: 215-223.

50. Beshkova DM, Simova ED, Frengova GI, Simov ZI, Dimitrov ZhP (2003) Production of volatile aroma compounds by kefir starter cultures. Int Dairy $\mathrm{J}$ 13: 529-535.

51. Formisano M, Percuoco G, Percuoco S (1972) Microbiological investigation of fermented milk drinks. Gas chromatography of the fatty acids in yoghurt. Dairy Sci Abst 34: 1763.

52. Menéndez S, Centeno JA, Godínez R, Rodríguez-Otero JL (2000) Effects of Lactobacillus strains on the ripening and organoleptic characteristics of ArzúaUlloa cheese. Int J Food Microbiol 59: 37-46. 